\title{
IMPROVING DRAMA SCRIPT WRITING THROUGH MODELING STRATEGIES
}

(Action Research in SMA of Purbolinggo Lampung)

\author{
Suyud Widodo ${ }^{1}$, Ninuk Lustyantie ${ }^{2}$ \\ Senior Hight School 1 Purbolinggo Lampung ${ }^{1}$ \\ State University of Jakarta ${ }^{2}$ \\ suyudwidodo12@gmail.com ${ }^{1}$ \\ ninuk.lustyantie@unj.ac.id ${ }^{2}$
}

\begin{abstract}
This action research refers to Elliot model (1991) that aims to improve the ability of writing a screenplay through modeling strategies. This action researchon SMA of Purbolinggo Lampung in the academic year of 2014/2015. The implementation of this research is three cycles. Each implementation of actions is divided into stages, identifying intial idea, reconnaissance, general planning, implement of action, monitor implemention, reflection, reconnaissance and revise general idea. The results of the reflection activities function as a foothold to draw up a plan of action to the next cycle. The research results can be concluded: the first process of improving writing skills through drama script modeling strategy. Second, the results of the upgrade script writing drama through modeling strategies, ranging from initial tests as exploitation of the capabilities of the beginning to the end of the test third cycle the experience increased. (1) The results of initial tests average score 40.1 ((level less); (2) the first cycle the average score 42.4 (level less); (3) the second cycle the average score 64.3 (level of being); and (4) the third cycle the average score 83.4. This score has already reached a high level.
\end{abstract}

Key words: lity of drama script writing, drama script writing through modeling strategy, modeling strategy.

Hassanudin WS stated that students are able to interest drama script in artistic and imaginative way when it is on teaching learning process, if it is continued on the movement performance and the act reality seen by the audiences (2009:1). However, the students are difficult and feel not able to write and reveal the idea and the thought by themselvesif they are asked to write the script. Thompson stated that writing drama script is the language activity which has the purpose to make the students develop their language ability on appreciates the literature work, so that they can get their interaction on society (2005:14).

Based on that reason, writing ability needs attention and sincerity from all elements of educator administrator. Hopefully, the students can be active, creative and innovative in following writing learning activity. Active learning means that the students will diffuse on the teaching learning process, be active demanding and answering and always give the alternative answer if they are asked to utter the opinion by the teacher.

Otherwise, the students are passive learners if theyonly sit, keep silence and do not want to get involve on learning activity. They are not interested in writing drama script and impact is they do not know how to write and how to open in revealing the theme, message, 
character and characterization, developing the plot and what the dialogue is expected. This case is the same with the students on SMA Negeri 1 Purbolinggo Lampung which give an effect on the under average score of 80 oncompleting minimum criteria (KKM) on the ability of drama script writing on 2014/2015 (KKM 2014/2015 SMA Purbolinggo Lampung Curriculum). When it was conducted the training, the students only got 64 as the highest score, 31 for the lowest score and the average score is 40.1 far from KKM.

In line with Kinayati (2009:10), the way the teacher conducted teaching learning process as above should be finished and have to get more serious attention because the teacher should make teaching learning strategy which can improve the students to be dynamic and they can be easy to get the meaningful interaction. How the teacher motivates students to do script writing is needed because it can make them develop,delicate and have the character, be adult human, be able to build the imagination, feeling and the thought, creates critical society, be independent, expressive, and be good achievement.

Accordingly, teaching script drama writing has to deal with the practice not the theories. Keke (2013:207) stated that the students are trained to see the object directly with the variation examplesperiodically through the exercise with theappropriate level before they make a written product. The expectation of this strategy is to drive the students'imagination about the drama script model exactly. In the fact, the learning process will be effective if it is supported by the model which can be imitated in psychiatric and physically, so that they can find and develop the concept in drama script (Hanafiah, 2012:74).

This research emphasized on the drama script writing ability development in modelling application. The focus research is as follow:

1) The increasing process on drama script writing through modelling strategy.

2) The increasing result on drama script writing through modelling strategy. Statements of the problem of this research are on below:

1) How does the process to increase the students' ability in drama script writing through the modelling strategy?

2) How does the result of increasing the students' ability in script drama writing through the modelling strategy?

This research is expected to give benefit as follows?

1) Theoretically, it is as a contribution to the academic thought and as the research resource, evaluation and reflection of some possibility strategies in high school level at the future.

2) Practically, the result of this research is used as the concrete reference for the teacher to increase the drama script writing on the various strategies. The other is students can receive meaningful learning experience on it.

The purpose of classroom research in this research is as the teacher effort to increase and repair the learning supervision quality. According to Suwarsih (2011:4) classroom research can be used to improve learning process and give the chance to the teacher to make an improvement, conduct the research to the learning activity for the correction. Stringer (2007:1) also stated if action research is systematic approach to the investigation that enables people to find the effective solutions to problems they confront in their everyday lives.

Whereas, the drama script writing ability is the skill in telling the information on fiction actor content on some scenes of the performance. It is also can be enjoyed by the readers if it is still on the script. Drama is the reflection of high value morality on the action scene. Nathalia (2011:83) stated that the ability is about the confident or the feeling that they can be optimistic, creative and dynamic people. The ability which has by someone is 
like be able to have physical potential movement and psychology, so that they can achieve the successful.

Writing is very important to us as the communication's tool. It can create the idea, thought and feeling, as the tool for revealing the knowledge and life experience on writing language. Furthermore, it can influence the way people are thinking. They will drive themselves to be active and creative, organize on do the action and have the logical thinking (Axelord, 2010:1). The other statement from Salam is writing can make someone in revealing esthetical spirit because someone who always tries to be creative writer will have the good esthetical spirit (2009:24).

Drama according to O'Toole is a group activity of some people in direct or indirectly in the different function. Although they take the scene individually, they have to have the connectivity and support one and other (2005:6). However, drama is also created to be read as the script, they are interesting as the entertainment (Husnul, 2010:1).

Drama has intrinsic and extrinsic elements. Intrinsic according to Hasanudin is about the character, characterization, motivation, conflict, event and plot (setting and place), how the language does applied, theme and message. Extrinsic is the author's life, knowledge, technology, socio culture, human right, religion, education, etc. (200:70-103).

The discussion on the elements of drama: the first is the theme which is about how the writer takes the topic as the discussion background through the indicator on the topic (A.Rahmat, 2008:29). The other is based on Heru, the theme is the core issue faced by the character on the story (2014:79). The second is the message based on Gunawan is uttered by the author to the readers or audiences trough the play. The statement from B.rahmanto, there are two way for uttering the message, those are implicit and explicit $(2011,5: 34)$.

The third is important because it is aboutthe character and characterization. There is no play without characterization or there will be no plot (Sentosa, 2008:91). From the character based on Budiman, the characters on the play are not only protagonist and antagonist. The other is deuteragonis, tirtagonist and the helper (2015:50). Gunawan gives the explanation if the realization of the character can be achieved by the author in analytically (direct method) and dramatically (indirect method) (2008:115).

The fourth is the plot. It tells how the story occurs as the part of the scene. The entailment of those stories on that scene should be analysed based on the whole plot (Rapi Tang, 2008:103). The plot is going to be good if it is on the clear series and not flat. Winata stated that the plot should resemble the graphic which is high and low dynamically (2015:105). The plot goes to climax and made into complicated. At this stage, the audiences are made thump and curious and want to know the ending. The ending will be represented in sadness or happiness.

The fifth is conflict element. Based on Abdulah it can be by person and person or person with around nature or with that person (her or his self) or we can state as the ability and the inner voice (2007:57). However, Kusnadi said that the conflict is grouped on one event (physic and mental) (2009:170).

The sixth is setting. Inside the play, setting is created to make the event representation runs clearly. Kusnadi continued that setting refers to the place explanation, timing relationship and social environment in the setting of the event (2009:171). The readers or the audiences will be delivered to the setting imagination where the time and the situation on that event occur. Therefore, they are easy to operate their imagination in figuring place, time and situation.

The seventh is language and dialogue, the feature of main character on the play is the actor is put on the dialogues (interview) from the actors (Abdulah, 2007:62). Dialogue is used to figure out the thought and the feeling of the character on the play. It should be directional and measured. The characters have to speak clearly and at the point. The 
dialogue has to be aesthetic. It means that having good language and represents the character played. When they play the drama, they have to be same on the traits based on the story. According to Heru, language on dialogue which is chosen short and simply, it does not contain metaphor deviate (2014:79).

The eighth is direction technic. Based on Maurinda, it is about the direction which is included deliberately by the author as the direction to render for those who want to perform it (2010:11). Drama scriptneeds technic direction which is often stated as the side text (Waluyo, 2001:29). This side text can give the direction about drama component.

The ninth is moral value in education, it is about extrinsic element. Particularly, the author used extrinsic element for influencing how does the play is created and how the actor is going to be. The main goal of this case is off course to give the moral value. On his statement, Suwardi stated that drama contained education situation context like how to reflect the material on the play (2011:289),so that the extrinsic element approach can be done in education moral value.

In line with the modelling strategy, Riyanto stated that the strategy used in learning process is the way the teacher makes the learning process effective and efficient. The goal is to make the optimal interaction between the students using learning component (2014:132). When the teacher does teaching learning process from drama script as the model, the students are asked to imitate and follow how to write and decide the rule based on their style. That model can be an inspiration for the students to create the play but they cannot make it on the same way like the model. They only can take the imagination from the model, so that they will be able to create the drama script.

There are some phases based on A. Bandura on teaching learning process which should be done by the teacher. There are attentional phase, retention phase, reproduction phase and motivation phase. Those kinds of phases will represent the learner's performance (1986:51). The first phase is the interesting attention which can drive into the interest. The second phase is retention. It is the repetition learning. The third is production process from the imagination into the true character performance. The fourth is student's motivation to imitate the model. The other function which prepared by the teacher based on Solchan refers to the abstract like concept, behaviour and creativity. It can be difficult and concrete, simple or easy because of the model figure (2013:136).

The drama script activity can support the students to imagine and as the tool to be creative students. To conduct this activity, Emzir stated that there are steps which should be applied by the teacher like exploring, interpretation, recreation (2015:267-268). The teacher has to understand about the literary work on teaching drama script. She is not only give the knowledge but also appreciation and expression.

The appreciation activity begins from the introduction, understanding and total comprehension until the drama production and performance (Suwardi, 2011:151-152). Appreciation learning has two targets like performance production and response when they see the play. The main goal of learning drama according to B. Rahmanto is to know how the character has to introduce the play on the drama performace (2011:90).

The steps which have to be done in teaching learning trough modelling strategy based on Maurinda is choosing the drama script first as the model and then read it, the next is find out the author's thought and give attention to see the systematic until find the script pattern. After that we can find out the idea written in the same pattern. Reveals it on the script follows the model, reread the script, do editing and ask the other person or teacher to read and give comment (2010:60-61).

This research is action research using Elliot model. It conducted at 33 students in science department of SMA Purbolinggo Lampung (2014/2015). This research is design in three cycles. Every cycle contains problem identification, field observation, 
reconnaissance, action, monitoring, reflection, field checking and revise from the first cycle. The data collection used in this research is observation, field note, interview, questionnaire and writing drama script.

\section{RESULT}

The research result is grouped by two types like the following:

1) The drama script ability increasing process through modelling strategy.

At section one, it can be seen on teaching writing script drama observation using "PerempuandalamKereta" model that the students did not active yet in this process, it is not interesting for them and did not well occur. There was not creative discussion, uninteresting, they were not do communicative on learning. There were students who were not join into discussion and unmotivated to do the activity, the students were passive, impassionate and unproductive, unwilling, will, motivation and the ability to write drama script well, so that they only had 2.5 average scores or it can be called as "not good".

The second section used drama script model entitled "MajalahDinding". The teaching learning process runs existence with the answers variation from the students. They looked active and creative, there was pleasure situation and it occurred well. However, the learning innovation and students learning effort evaluation had not look yet. There were some students who did not join to the discussion. The creativity also had not looked; so that the average score on second cycle is 3.1 (good).

The third section used drama script model entitled "Ibu". The process run well based on the expectation. The students were active and enjoy the process. The discussion process looked creative, interesting and they had good communication each other. They get involved to discuss, high motivate to do the process and had encourage writing ability. The students are able to reveal the idea when the teacher asked them to write, the impact is the research purpose can be achieved. That means that the teaching learning implementation based on modelling strategy principles gives the positive impact through the teaching learning process, so that the average score achieved is 3.8 (it is between good and very good).

Based on the observation above, the script drama writing process from the first until section three, there was the differences ability from every student as the individual and the member of the group discussion in line with the liveliness, creativity, innovation and evaluation $\mathrm{n}$ writing activity based on the problem in this research.

\section{2) The result of drama script ability increasing process through} modelling strategy.

The first implementation test is to measure the students' ability before teaching learning process is done. From this activity, it showed that the lowest score is 31 , the highest score is 64 and the average score is 40.1 . This ability is the same with 29 students or $87.9 \%$ on poor ability. There were 4 students or 12.1 on enough ability and the best ability is not found or $0 \%$.

When the teaching learning modelling strategy implementationgave 31 lowest score, the highest score is 70 and the average score is 42.4 . This result is the same with 25 students or $75.8 \%$ on poor ability, 8 students or $24.2 \%$ at enough ability and $0 \%$ at the best ability. There was enhancement on second section of the process. It is showed by the 48lowest score, the highest score is 84 and the average score is 64.3. Those score are the same with 4 students or $12.1 \%$ in the poor ability or $21.2 \%$ in the best ability. 
In conducting the third section, the lowest score is 73 , the highest score is 90 , and the average score is 83.4 . This score is the same with $0 \%$ in the poor students' ability, 6 students or $18.2 \%$ in enough ability and 27 students or $81.2 \%$ in the best ability. Those results can be seen in the following:

1. The average test got enhancement is around 19.1. From 64.3 on section two, there is 83.4 enhancement on section three.

2. The score distribution of 27 students or $81.2 \%$ in the high ability, 6 students or $18.2 \%$ on enough ability and $0 \%$ on the poor ability.

3. The average score is 83.4 . It is more than 80 completing minimum criteria standard (KKM). Although there was still find the lowest score on the individual below KKM, 12 students from 33 students. They still can achieve 75.6.

If we see on the achievement until section three, the significant score is achieved on the ability of script drama writing even it is more than completing minimum criteria standard (KKM). This achievement is because of the implementation of modelling strategy which can motivate the students to create imagination idea.

Below is the graphic on the ability of script drama writing.

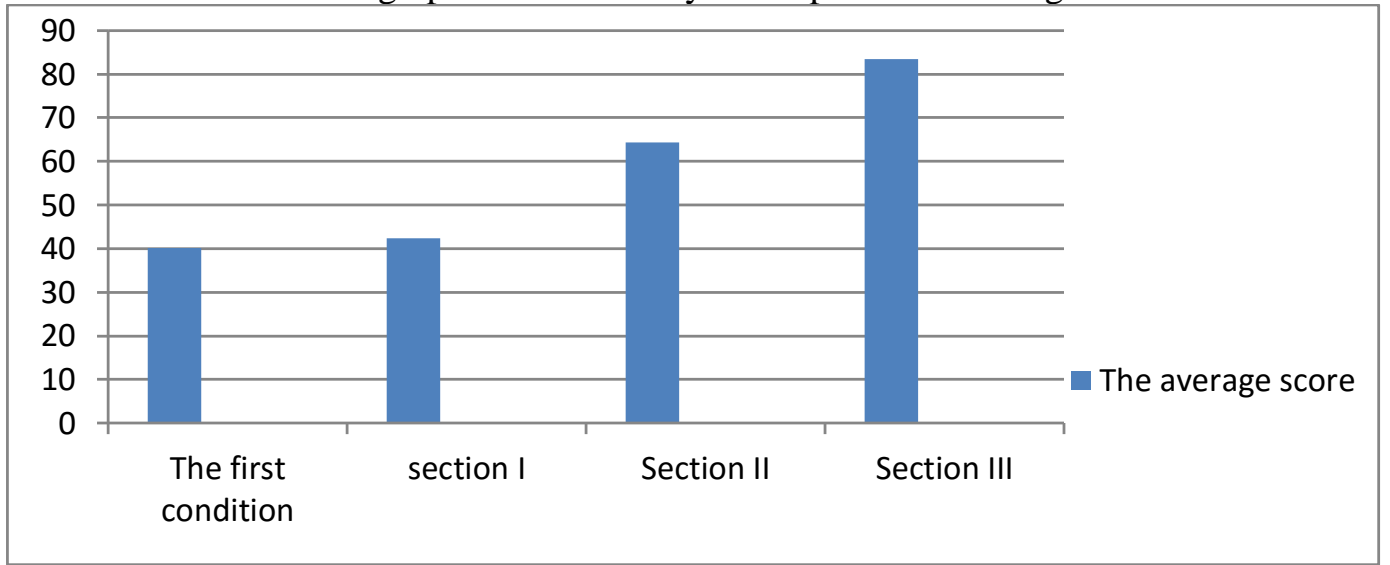

The data above showed that there is the increasing ability on drama script writing from the first score until section three. Furthermore, to make it clearly in every element through the script drama on the students can be seen in the following.

Table 1 . The average score in revealing the drama elements

\begin{tabular}{|c|l|c|c|c|c|}
\hline No. & The Drama Elements & TA & S I & S II & S III \\
\hline 1 & Theme & 38,5 & 40,9 & 65,2 & 84,5 \\
\hline 2 & Message & 41,2, & 42,4 & 67,0 & 84,8 \\
\hline 3 & $\begin{array}{l}\text { Character and } \\
\text { Characterization }\end{array}$ & 43,6 & 45,4 & 67,3 & 85,8 \\
\hline 4 & Plot & 46,1 & 49,4 & 67,9 & 86,1 \\
\hline 5 & Conflict & 31,7 & 33,1 & 54,5 & 79,6 \\
\hline 6 & Setting & 48,2 & 49,7 & 71,5 & 90,0 \\
\hline 7 & Language and Setting & 32,7 & 34,8 & 60,2 & 75,8 \\
\hline 8 & Technique Direction & 47,9 & 52,7 & 67,0 & 85,5 \\
\hline 9 & Moral Education & 40,3 & 43,0 & 65,5 & 84,5 \\
\hline
\end{tabular}

To make that graphic clearly, there is a graphic shows the significant script drama writing ability on below.

Graphic 2. The Average Scores in Revealing The Drama Elements 


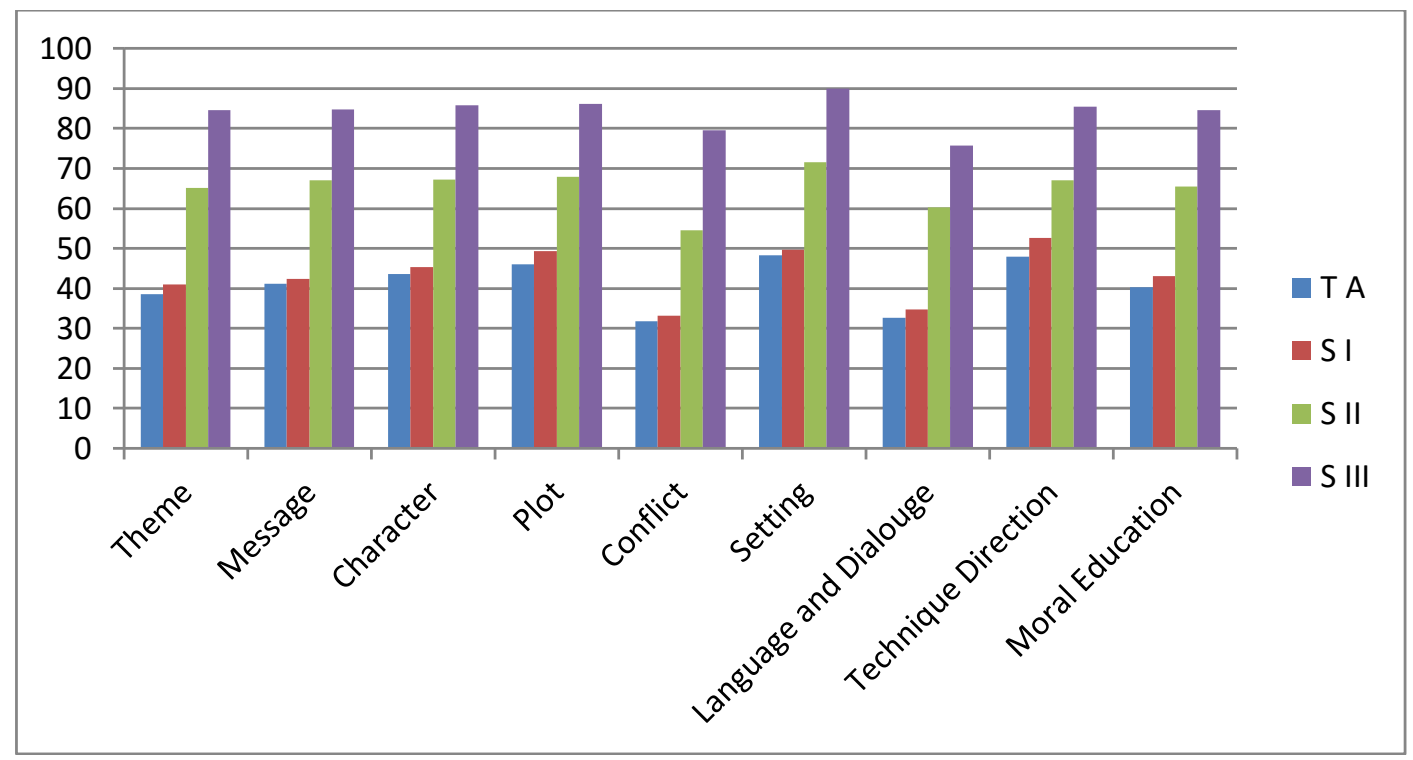

DISCUSSION

1) The drama script ability increasing process through modelling strategy.

The first section in drama script teaching learning process did not occur optimal yet like the low enthusiasm students participation, students' action is not innovative, did not creative yet, there was no evaluative changes. However, on section two, there was active students' participation, creativity, evaluative but there was no innovative character which can be applied.

The lineless, creativity, evaluative and innovative students can be seen on section three on this process implementation. This happen because there is reflection in final section by the researcher and the observation based on the interviewed with the students. The questionnaire and the picture are as the tools in the students' activity.

2) The result of drama script ability increasing process through modelling strategy.

There was significant result when the research was conducted. The third section result is categorized on the best students' ability from the first test section. There was enhancement is 43.3 on the ability of the students from the first section is 2.3 and 21.6 on the second section and then 19.4 on the third section.

From 80 as the achievement of completing minimum criteria standard $(\mathrm{KKM})$, there was first test with the highest score 63, it means that the students were on below KKM. On the first test, there was also 70 means they did not achieved KKM. However, on the second section final test, the highest score is 82 and there were 4 students got more than KKM standard. On the third section, there is 90 with the average score 83.4 at more KKM result, although there were 12 students did not achieve KKM yet.

Besides seeing with comparing KKM achievement, the third section score can be seen from score distribution with the best ability score criteria, enough or poor. If it is seen based on the aspect, there were 27 students on the highest ability and 6 students on enough ability and then there were no students in the poor ability.

\section{CONCLUSION}

The core of modelling strategy is very important for the students with the difficulty of drama script writing trough the problem identification, field observation, planning, 
action, monitoring, field checking, and do revision on section of the process. There found the cases on every action which has to repair on the next research process.

From this research, it can be took that: 1) there was significant enhancement process on the ability of students in writing drama script on SMA Purbolinggo Lampung after the implementation of modelling strategy. The increasing process can be seen with the enhancement score section process from section one is 2.5 to 3.1 on section two and on section three is 3.8.2) there is significant enhancement on the first test in the average score is 40.1 , the first section test is 42.4 , second section is 64.3 and section three is 83.4 there is average score 83.4 achieved KKM 80 and there is the high ability is $81.8 \%$.

Based on this conclusion, it can be took that teaching learning drama script writing through modelling strategy can increase the ability of the students. Generally, the students can be creative and create the literary work.

\section{REFERENCES}

Achmad, Sri Wintala. Panduan Lengkap Menjadi Penulis Handal. Yogyakarta : Araska. 2015

Akbar, Budiman. Semua Bisa Menulis Skenario, Jakarta : Erlangga.2015

Aritonang, Keke Taruli. Catatan Harian Guru : Menulis itu Mudah. Yogyakarta : Andi. 2013.

Axelrod, Rise B. Rise B. Charles R.Cooper.The ST. Martin's Guide to Write. Boston: Bedford/ St.Martin's.2010.

Bandura, Albert.Sosial Foundations Of Thought And Action A Sosial Cognitive Theory. USA : Pearson Education.1986.

Budi Santoso, Gunawan. Wendi Widya, R.D., Uti Darmawati; editor Kuswilono. Terampil Berbahasa Indonesia: untuk SMA/MA kelas XI. Jakarta: Pusat Perbukuan. Depdiknas. 2008.

Djojosuroto, Kinayati dan Surastina. Pembelajaran Apresiasi Sastra. Yogyakarta : Pustaka Book Publiser. 2009.

Dola, Abdullah. Apresiasi Prosa Fiksi dan Drama.Makasar : Badan Penerbit UNM. 2007.

Elliott, John. Action Research For Educational Change. Philadelphia : Open University Press Milton Kyenes.1991

Emzir. Saifur Rohman. Teori dan Pengajaran Sastra. Jakarta : Raja Grafindo Persada.2015. 

2011.

Endraswara, Suwardi. Metode Pembelajaran Drama. Yogyakarta : CAPS.

Fariyanti, Maurida. Mendengarkan dan Memahami Isi Drama. Bogor : Quadra. 2010.

Hanafiah, Nanang dan Cucu Suhana. Konsep Strategi Pembelajaran. Bandung : Refika Aditama. 2012.

Husnul, Ade dan Hadiyati, Nurul. Bermain Opera. Bogor : Horizon. 2010

Kemmis, Stephen. Roben McTaggart Rhonda Nixon. The Action Research Planner.Singapore: Springer Singapore Heidelberg New York Dordrecht London.2014

Kurikulum SMA Negeri 1 Purbolinggo Lampung Timur, Lampung. $2014 / 2015$

Kurniawan, Heru. Pembelajaran Menulis Kreatif Berbasis Komunikatif dan Apresiatif. Bandung : Remaja Rodakarya.2014.

Kusnadi,E. Andang Purwoto. Siti Aisah. Belajar Efektif Bahasa Indonesia. Jakarta : Pusat Perbukuan Depdiknas.2009

Madya, Suwarsih. Penelitian Tindakan Action Research Teori dan Praktik. Bandung : Alfabeta. 2011.

Nursiti, Nathalia.Pengembangan Kepribadian Bagi Para Profesional. Banten: Dinas Pendidikan Banten.2011

Rahmanto, B. S.Indah Peni Adji. Drama. Jakarta : Universitas Terbuka.2011.

--------,Metode Pengajaran Sastra.Yogyakarta : Kanisius.2005.

Rafi Tang, Muhammad. Mozaik Dasar Teori Sastra. Makasar : Badan Penerbit UNM.2008.

Rosyadi, A.Rahmat. Menjadi Penulis Profesional itu Mudah. Bogor :Ghalia Indonesia. 2008.

Riyanto, Yatim. Paradigma Baru Pembelajaran, Jakarta : Kencana Prenada Media Group, 2014.

O'Toole, John. The Process of Drama Negotiating and Meaning. London and New York : Routledge. 2005

Salam. Pendidikan Penulisan Kreatif. Makasar : Badan Penerbit UNM.2009. Santosa, Eko. dkk, Seni Teater Jilid 1. Jakarta : Depdiknas.2008. 
Thompson, Gill and Huw Evans. Thingking it Through. London: David Fulton Publishers, ltd. 2005.

T.Stringer, Ernest. Action Research. Singapore :Sage Publications AsiaPasific Pte Ltd. 2007.

Waluyo, Herman J..Drama Teori dan Pengajarannya. Yogyakarta : Hanindita Graha. 2001.

WS, Hasanuddin. Drama Dalam Dua Dimensi. Bandung : Angkasa, 2009. 